\title{
Protein Expression in Pig Species Longissimus dorsi Muscles among Different Breeds and Growth Stages
}

Byung Uk $\mathrm{Kim}^{1+}$, Sam Woong $\mathrm{Kim}^{2^{+}}$, Yeon Hee Hong', Mi Ae Jeong', Yeon Sun Ryu ${ }^{3}$, Hwa Chun Park', Jong Hyun Jung, ${ }^{4}$, Young Min Kwon', In Soon Choi ${ }^{6}$, Sang Suk Lee ${ }^{7}$, Chul Wook Kim ${ }^{1}$ and Kwang Keun Cho *

\author{
${ }^{1}$ Department of Animal Resources Technology, Gyeongnam National University of Science and Technology, Jinju 660-758, Korea \\ ${ }^{2}$ Swine Science \& Technology Center, Gyeangnam National University of Science and Technology, Jinju 660-758, Korea \\ ${ }^{3}$ Department of Animal Health Management, Woosuk University, Wanju-gun, Jeonbuk, 565-701, Korea \\ ${ }^{4}$ Dasan Genetics, Gasan-ri, Unbong-ub, Namwon-city Jeonbuk, Korea \\ ${ }^{5}$ Department of Poultry Science, University of Arkansas, Fayetteville, AR 72701, USA \\ ${ }^{6}$ Department of, Silla University, Busan, 617-736, Korea \\ ${ }^{7}$ Department of Animal Science and Techndogy, Sunchon National University, Suncheon 540-742, Korea
}

Received May 29, 2012 /Revised June 7, 2012 /Accepted June 11, 2012

\begin{abstract}
When proteins extracted from longissimus dorsi muscles of Landrace and Berkshire at the finishing stage were compared by 2-DE, the Landrace demonstrated a quantitative increase in proteins related to slow skeletal muscle function, such as serum albumin precursor, troponin $\mathrm{T}$ (slow skeletal muscle; sTnT) and myoglobin. In contrast, the Berkshire exhibited comparatively elevated enzymes involved in metabolic pathways, fast skeletal muscle function, and energy production, such as heat shock 27-kDa protein (HSP27)-1, TnT (fast skeletal muscle; fTnT), muscle creatine kinase, phosphoglucomutase 1 (PGM1), triosephosphate isomerase (Tpi1) and adenylate kinase isoenzyme 1 (AK1). When compared to growing Berkshire, finishing Berkshire showed increased levels of aldehyde dehydrogenase 1 family, member L1 (ALDHL1), and muscle creatine kinase. In contrast, the growing Berkshire muscle had elevated levels of HSP27-1, sTnT, fTnT, serum albumin precursor, PGM1, AK1, and Tpi 1 as compared to the finishing Berkshire. The Landrace longissimus dorsi muscle may be composed of slower skeletal muscle, whereas Berkshire is composed of a faster skeletal muscle. The uniquely elevated quantities of proteins involved in skeletal muscle function, energy metabolism, and cytoskeleton function in the growing Berkshire indicate that these factors support growth and maintenance during the growing stage when compared with the finishing Berkshire.
\end{abstract}

Key words : 2-DE, Longissimus dorsi muscle, Berkshire, Landrace, pig

\section{Introduction}

The lineage of a pig with superior growth and meat quality is maintained in a specific heritage. Various investigators have identified changes in protein expression caused by genetic polymorphisms that directly impact the growth and/or meat quality of pigs or mice [6]. Although data regarding pig muscle properties and meat quality with respect to age and body weight are quite limited, increases in age and body weight are generally considered to result a more potent meat color and higher muscle fat content [5]. Otherwise, Beta-2 adrenergic receptors (ARs) regulate glycogenolysis, lipolysis and proteolysis in muscle and fat tissues [19]. The factors

\footnotetext{
†These authors contributed equally to this work.

*Corresponding author

Tel : +82-55-751-3286, Fax : +82-55-751-3280

E-mail : chotwo2@gntech.ac.kr
}

that affect beta-2 AR function, such as genetic polymorphisms, are predicted to influence meat quality and other attributes [10]. The myogenin gene has been studied for its contribution to the generation of lean meat content of pigs and especially how myogenin polymorphisms affect this content [6].

Among the very limited data gleaned from proteomics studies performed with pig tissue is a comparison between white and red muscle of embryonic and growing pigs [8]. Generally, proteomic studies with 2-DE results in approximately 300-500 protein spots. Among these spots, comparative proteomics with proteins from white and red muscle indicated differences in the expression of only a few proteins: myoglobin, two slow-twitch isoforms of myosin light chain and two small heat shock proteins [15].

To expand this field of knowledge, we investigated the differences in protein expression patterns in longissimus 
dorsi muscle tissue between finishing Landrace and Berkshire pigs, as well as between growing and finishing Berkshires.

\section{Materials and Methods}

\section{Animals and tissue harvesting}

To compare and analyze the expression pattern of proteins among different pig breeds and growth stages, four individual pigs were selected for each of finishing Danish Landrace and British Berkshire pigs (110 kg; Chonbuk Dasan Pig Breeding Co.). Four individual Berkshires were also selected for each of the growing $(60-70 \mathrm{~kg})$ and finishing stages (110 kg; Chonbuk Dasan Pig Breeding Co.). The selected animals were euthanized in accordance with the animal welfare regulations of the National Institute of Livestock and Grassland Science. Longissimus dorsi muscles were harvested from the euthanized pigs, snap-frozen in liquid nitrogen, and stored at $-80^{\circ} \mathrm{C}$ until used in experiments.

\section{Protein extraction from longissimus dorsi muscle}

Harvested longissimus dorsi muscle tissue $(100 \mathrm{mg})$ was sonicated for 10 seconds by Sonoplus (Bandelin Electronic, Germany) in the sample lysis solution made of $7 \mathrm{M}$ urea, $2 \mathrm{M}$ thiourea, $4 \%(\mathrm{w} / \mathrm{v})$ CHAPS, $1 \%(\mathrm{w} / \mathrm{v})$ DTT, and 2\% (v/v) pharmalyte, and $1 \mathrm{mM}$ benzamidine, and then directly homogenized by a motor-driven homogenizer (PowerGen125, Fisher Scientific). After the homogenized product was centrifuged at $15,000 \times g$ for one hour at $15^{\circ} \mathrm{C}$, the precipitated insoluble material was discarded, and the soluble supernatant fraction was collected and used for 2-DE. Protein quantity was normalized by Bradford assay for sample loading [4].

\section{Protein separation via 2-DE and gel image analysis}

An IPG dry strip $(130 \times 3 \times 0.5 \mathrm{~mm}, \mathrm{pH} 4-10$, GE Healthcare Bio-Sciences $\mathrm{AB}$ ) was incubated for 12-16 hours in a rehydration buffer (7 M urea, $2 \mathrm{M}$ thiourea, 2\% CHAPS, 1\% DTT, and $1 \%$ pharmalyte), and $1.1 \mathrm{mg}$ of each sample was loaded into a strip fixed in a strip module. IEF was performed at $20^{\circ} \mathrm{C}$ using a Multiphor II electrophoresis unit and an EPS 3500 XL power supply (Amersham Biosciences, USA) according to the manufacturer's instruction. The voltage for IEF was linearly increased from 150 to 3,500 $\mathrm{V}$ over three hours to allow for sample entry into the gel, followed by constantly applying 3,500 V for complete focusing until 96 $\mathrm{kVh}^{-1}$ was reached. Prior to electrophoresis, the treated strips were incubated for ten minutes each in equilibration buffer (50 mM Tris-Cl, pH 6.8, $6 \mathrm{M}$ urea, 2\% SDS and 30\% glycerol) with $1 \%$ DTT added to the first incubation and $2.5 \%$ iodoacetamide added to the second incubation. The equilibrated strips were inserted into SDS-PAGE gels $(20 \mathrm{x}$ $24 \mathrm{~cm}, 10-16 \%$ ) and protein separation via SDS-PAGE was performed by the Hoefer DALT 2D system (Amersham Biosciences, USA) according to the manufacturer's instructions. The 2-DE gels were run at $1,700 \mathrm{Vh}^{-1}$ at $20^{\circ} \mathrm{C}$, and were then stained by CBB G250 solution, as described by [1]. The 2-DE gels were gently incubated in colloidal CBB stain to allow for analysis of protein spots. The colloidal CBB solution was prepared by combining $177 \mathrm{ml} 85 \%$ phosphoric acid, $150 \mathrm{~g}$ ammonium sulfate, $1.8 \mathrm{~g}$ colloidal CBB-G 250 , adjusted to $1,200 \mathrm{ml}$ with water, and then finally adjusted to $1,500 \mathrm{ml}$ with methanol.

Quantitative analysis of digitized gel images was performed with the PDQuest software (version 7.0, Bio-Rad) according to the manufacturer's protocol. The quantity of each spot was normalized by total valid spot intensity. Protein spots with significant expression differences between pig group samples were selected for further analysis.

\section{Protein identification via PMF and CAF-MALDI sequencing}

Protein identification by PMF was performed as follows: Protein spots were enzymatically-digested in-gel with modified porcine trypsin in a manner similar to the method previously described by [22]. Target spots were cut from the gel and the gel pieces were washed with 50\% acetonitrile to remove SDS, salt and staining dye, then dried to remove solvent, rehydrated with digestive solution containing tryp$\sin (8-10 \mathrm{ng} / \mu \mathrm{l})$, and then incubated for $8-10$ hours at $37^{\circ} \mathrm{C}$. The proteolysis reaction was terminated by adding $5 \mu \mathrm{l}$ of $0.5 \%$ TFA. Tryptic peptides were recovered by combining the aqueous phases obtained from several extractions of gel pieces with 50\% aqueous acetonitrile. After concentration, the peptide mixture was desalted using $\mathrm{C}_{18}$ ZipTips (Millipore, USA) and eluted in 1-5 $\mu \mathrm{l}$ acetonitrile. An aliquot of this solution was mixed with an equal volume of a saturated solution of a-cyano-4-hydroxycinnamic acid in 50\% aqueous acetonitrile, and $1 \mu \mathrm{l}$ mixture was spotted onto a target plate.

Protein analysis via PMF was performed by an Ettan 
MALDI-TOF (Amersham Biosciences, USA). Peptides were evaporated with a $\mathrm{N}_{2}$ laser at $337 \mathrm{~nm}$ with a delayed extraction approach. The peptides were accelerated with $20-\mathrm{kV}$ injection pulse for TOF analysis. Each spectrum is the cumulative average of 300 laser shots. The search program ProFound developed by Rockefeller University (http://129.85.19.192/profound_bin/ WebProFound.exe) was used for protein identification by PMF. Spectra were calibrated using the trypsin auto-digestion ion peak $\mathrm{m} / \mathrm{z}$, 842.510 and 2211.1046, as an internal standard.

Chemically assisted fragmentation-MALDI (CAF-MALDI) sequencing was performed as follows: Protein digestion was performed by the same method with PMF as described above. Additionally, the 4-sulfophenyl-isothiocyanate (SPITC; Sigma-Aldrich) reaction was performed as per [9]. SPITC was dissolved at a final concentration of $10 \mathrm{mg} / \mathrm{ml}$ in $20 \mathrm{mM} \mathrm{NaHCO}_{3}, \mathrm{pH} 9.5$, and then treated by a half-volume of SPITC solution versus one volume of trypsin-digested solution. The reaction was allowed to progress for 30 minutes at $55^{\circ} \mathrm{C}$ and terminated by adding $1 \mu 15 \%$ TFA. The remainder of the protocol was performed by the same method used for PMF.

\section{Statistical analysis}

Statistical analysis was performed with SAS (Statistics Analytical System, USA, 1999) according to the general linear model (GLM). Duncan's Multiple Range Test was used to compare the differences of the means between samples. Data are expressed as mean \pm SD.

\section{Results and Discussion}

Protein expression differences in longissimus dorsi muscle between pig breeds

Various pig breeds are different with respect to growth and meat quality based on genetic lineage and protein expression pattern [6]. To identify differences in protein expression patterns between different breeds, we comparatively analyzed proteins from the longissimus dorsi muscles between finishing Landrace and Berkshire breeds. The protein profiles of the longissimus dorsi muscle were analyzed by 2 -DE via IEF and SDS-PAGE (Fig. 1). The average number of spots in the gels after staining with colloidal CBB was approximately 450 for each pig breed. Intensities of almost all spots between finishing Landrace and Berkshire were similar; however, the intensity of a few spots was different between groups.

Spots exhibiting varied intensity by gel image analysis were selected as proteins differentially expressed between groups. However, we only accepted the spots that were of altered intensity in at least three of the four samples analyzed in each group (data not shown). We identified intensity changes in 29 spots between the protein repertoire of Landrace and Berkshire pig longissimus dorsi muscle tissue (Fig. 1). By comparing protein quantity between the two breeds, we identified 10 spots that represented proteins either specifically expressed only in Landrace (SSP 4002 and 4101) or expressed at elevated levels in Landrace compared to Berkshire (SSP 4607, 4608, 5102, 5201, 5207, 5208, 5601,

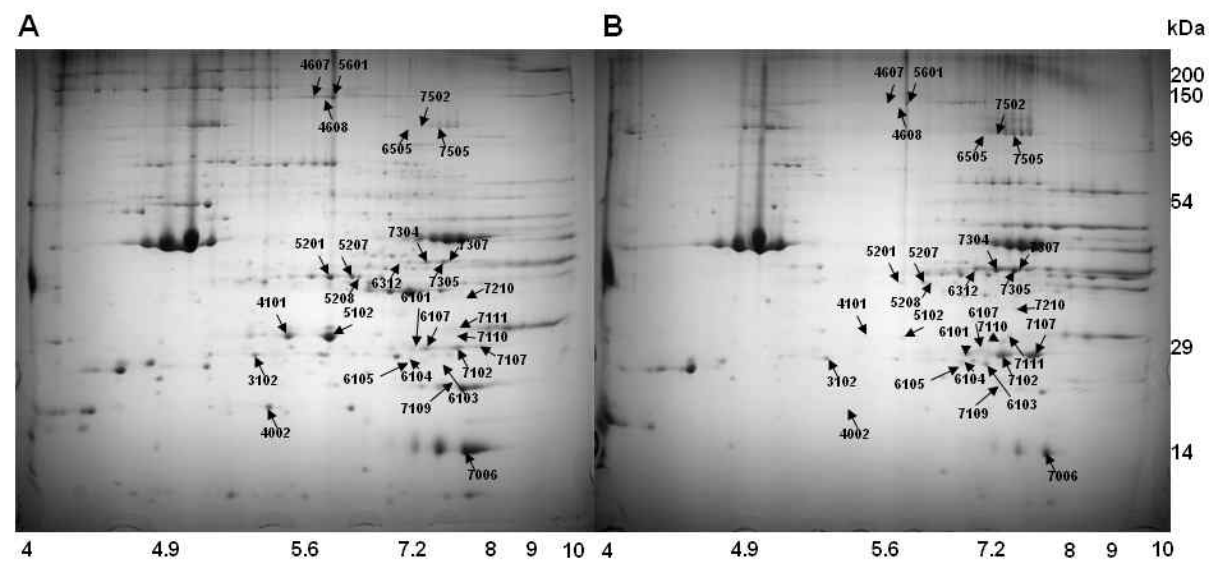

pH

Fig. 1. Comparative analysis of expressed protein pattern in Landrace and Berkshire longissimus dorsi muscles. Protein patterns of longissimus dorsi muscles of (A) Landrace and (B) Berkshire pigs. The spots that changed in intensity are marked with an identifying number. 
Table 1. Protein expression patterns in Landrace and Berkshire longissimus dorsi muscles

\begin{tabular}{|c|c|c|c|c|c|c|}
\hline $\operatorname{SSP}^{1)}$ & $\mathrm{MW}^{2)}$ & $\mathrm{PI}^{3)}$ & $\begin{array}{l}\text { Mean intensity } \\
\text { of } W^{4)}\end{array}$ & $\begin{array}{l}\text { Mean intensity } \\
\text { of } \mathrm{BA}^{5}\end{array}$ & $\begin{array}{l}\text { Fold variation: } \\
W \text { versus BA }\end{array}$ & $P$ value \\
\hline 3102 & 26.67 & 5.24 & $683.2 \pm 160.5704$ & $1190.6 \pm 426.7319$ & 0.57 & 0.820 \\
\hline $4002^{*}$ & 19.10 & 5.33 & $629.2 \pm 191.47$ & - & - & - \\
\hline $4101^{*}$ & 29.57 & 5.46 & $543.5 \pm 840.481$ & - & - & - \\
\hline 4607 & 72.74 & 5.67 & $631.6 \pm 30.05204$ & $215.1 \pm 95.6091$ & 2.94 & 0.170 \\
\hline 4608 & 72.64 & 5.84 & $1081.7 \pm 220.9002$ & $291.5 \pm 99.28095$ & 3.71 & 0.070 \\
\hline 5102 & 29.46 & 5.89 & $2600.5 \pm 2663.933$ & $200.7 \pm 62.16772$ & 12.96 & 0.190 \\
\hline 5201 & 36.46 & 5.90 & $2597.1 \pm 1349.202$ & $503.3 \pm 152.721$ & 1.93 & 0.090 \\
\hline 5207 & 36.54 & 6.22 & $2013.1 \pm 663.2540$ & $810.4 \pm 340.2541$ & 2.48 & 0.190 \\
\hline 5208 & 36.50 & 6.32 & $1221.2 \pm 378.4666$ & $312.3 \pm 135.4965$ & 3.91 & 0.110 \\
\hline 5601 & 72.71 & 5.94 & $590.0 \pm 278.7477$ & $222.3 \pm 93.31052$ & 2.65 & 0.170 \\
\hline 6101 & 27.86 & 6.79 & $1121.7 \pm 360.6687$ & $2117.0 \pm 275.6112$ & 0.52 & 0.004 \\
\hline 6103 & 26.13 & 7.06 & $160.8 \pm 118.9443$ & $1031.8 \pm 661.6153$ & 0.16 & 0.040 \\
\hline 6104 & 26.44 & 6.70 & $18.0 \pm 3.407262$ & $254.0 \pm 141.5931$ & 0.07 & 0.020 \\
\hline 6105 & 26.00 & 6.68 & $7.1 \pm 4.2659$ & $241.0 \pm 135.3298$ & 0.03 & 0.001 \\
\hline 6107 & 28.69 & 6.97 & $193.4 \pm 99.89321$ & $633.9 \pm 113.8523$ & 0.31 & 0.001 \\
\hline 6312 & 38.43 & 6.96 & $326.0 \pm 61.19987$ & $1500.3 \pm 455.4619$ & 0.22 & 0.020 \\
\hline 6505 & 65.89 & 6.97 & $286.8 \pm 149.751$ & $1178.6 \pm 87.33367$ & 0.24 & 0.005 \\
\hline 7006 & 14.43 & 8.22 & $7994.0 \pm 1378.333$ & $4368.1 \pm 1093.182$ & 1.83 & 0.200 \\
\hline 7102 & 27.83 & 7.55 & $3190.8 \pm 616.0017$ & $7284.7 \pm 815.0820$ & 0.44 & 0.020 \\
\hline 7107 & 27.98 & 8.07 & $6167.5 \pm 2856.350$ & $11787.4 \pm 2639.7080$ & 0.52 & 0.020 \\
\hline 7109 & 23.37 & 7.47 & $161.7 \pm 165.7149$ & $606.9 \pm 66.13413$ & 0.27 & 0.060 \\
\hline 7110 & 29.83 & 7.56 & $11.5 \pm 17.45701$ & $449.8 \pm 241.3508$ & 0.03 & 0.060 \\
\hline 7111 & 30.48 & 7.65 & $29.8 \pm 8.593581$ & $268.3 \pm 134.2736$ & 0.11 & 0.020 \\
\hline 7210 & 33.02 & 7.80 & $21.6 \pm 9.957578$ & $233.1 \pm 182.741$ & 0.09 & 0.060 \\
\hline 7304 & 38.46 & 7.56 & $2416.6 \pm 390.2600$ & $3579.1 \pm 1152.280$ & 0.68 & 0.490 \\
\hline 7305 & 38.48 & 7.83 & $2065.4 \pm 478.6041$ & $3253.2 \pm 1593.737$ & 0.64 & 0.200 \\
\hline 7307 & 38.60 & 7.91 & $1181.5 \pm 423.1873$ & $2615.1 \pm 1270.187$ & 0.45 & 0.350 \\
\hline 7502 & 65.89 & 7.20 & $445.9 \pm 142.9668$ & $1506.3 \pm 308.3955$ & 0.30 & 0.001 \\
\hline 7505 & 66.02 & 7.69 & $467.5 \pm 44.47702$ & $1346.3 \pm 111.0929$ & 0.35 & 0.001 \\
\hline
\end{tabular}

SSP, standard spot protein; MW, molecular weight by kDa; PI, isoelectric point; W, Landrace; BA, Berkshire. Spots of greater intensity in Landrace are indicated by bold font. *Spots detected at only Landrace.

and 7006). The other 19 of 29 total spots represented proteins expressed at elevated levels in muscle from Berkshire compared to those of Landrace (Table 1).

Protein expression differences in longissimus dorsi based on growth stage of the Berkshire breed

Because the Berkshire pig is generally known for its superior meat quality compared to the Landrace pig, we chose the proteins of the Berkshire longissimus dorsi muscle by 2-DE to investigate the protein expression pattern of this breed according to growth stage. We performed 2-DE on muscle tissue from the Berkshire at growing and finishing stages and observed about 450 spots (data not shown). We sought to select the spots that exhibit differential expression consistently between the two growth stages and identified 12 specific spots (Fig. 2).

By comparing the protein expression in Berkshire according to growth stages, we found that the protein expressions of 9 of the 12 identified spots were elevated in the growing Berkshire versus finishing. We identify three spots, SSP 7110, 7111 and 7210, that were expressed more highly in the finishing pig. These proteins may be essential for initial growth of the Berkshire pig (Table 2).

Self-organizing map clustering (SOM) was performed for analysis of expression pattern of the spots exhibiting specific changes according to breed and growth stages (data not 


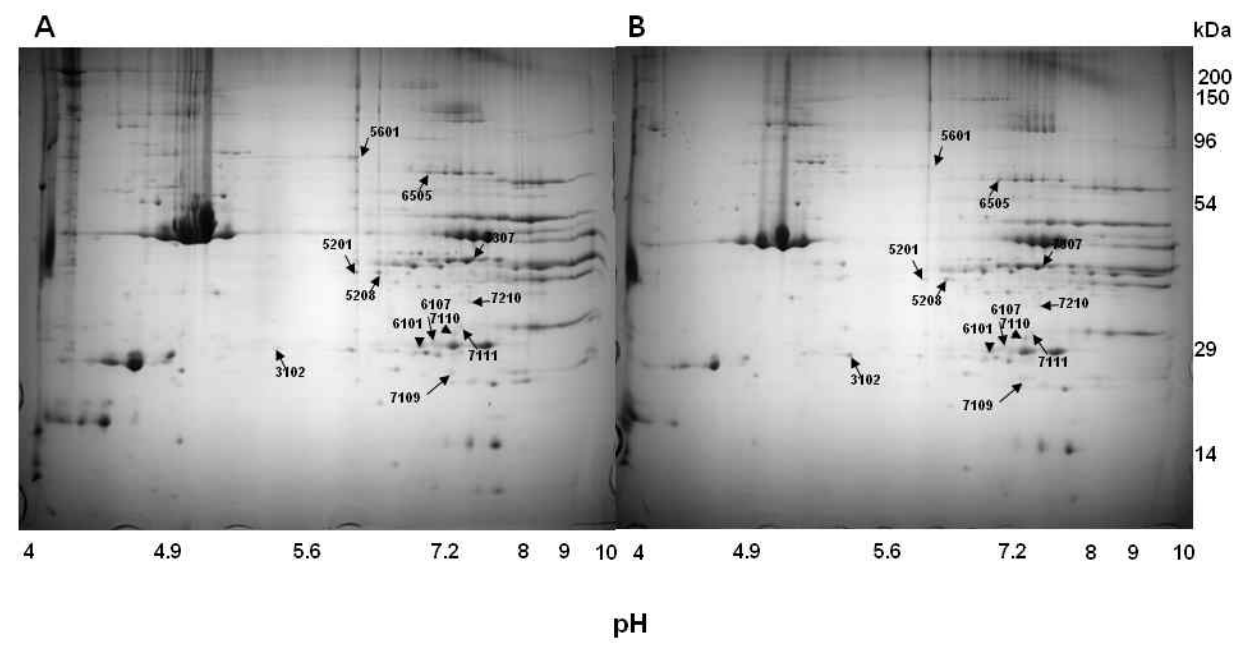

Fig. 2. Comparative analysis of expressed protein pattern between growing and finishing Berkshires longissimus dorsi muscles. Protein patterns of longissimus dorsi muscles of (A) growing and (B) finishing Berkshire pigs. The spots that changed in intensity are marked with an identifying number.

Table 2. Protein expression patterns in longissimus dorsi muscles of growing and finishing Berkshires

\begin{tabular}{ccccccc}
\hline SSP & MR & PI & $\begin{array}{c}\text { Mean intensity } \\
\text { of GB }\end{array}$ & $\begin{array}{c}\text { Mean intensity } \\
\text { of FB }\end{array}$ & $\begin{array}{c}\text { fold variation: } \\
\text { GB versus FB }\end{array}$ & P value \\
\hline 3102 & 26.67 & 5.24 & $1190.6 \pm 426.7319$ & $395.0 \pm 174.1998$ & 3.01 & 0.057 \\
5201 & 36.46 & 5.90 & $569.6 \pm 92.9584$ & $287.2 \pm 78.28379$ & 1.98 & 0.700 \\
5208 & 36.50 & 6.32 & $312.3 \pm 135.4965$ & $44.9 \pm 27.80366$ & 6.96 & 0.025 \\
5601 & 72.71 & 5.94 & $180.7 \pm 112.914$ & $132.5 \pm 51.6912$ & 1.36 & 0.470 \\
6101 & 27.86 & 6.79 & $2117.0 \pm 275.6112$ & $1495.8 \pm 160.3946$ & 1.42 & 0.008 \\
6107 & 28.69 & 6.97 & $633.9 \pm 113.8523$ & $338.2 \pm 192.3229$ & 1.87 & 0.030 \\
6505 & 65.89 & 6.97 & $1178.6 \pm 87.33367$ & $618.7 \pm 147.1811$ & 1.91 & 0.157 \\
7109 & 23.37 & 7.47 & $606.9 \pm 66.13413$ & $246.2 \pm 73.60982$ & 2.47 & 0.208 \\
7110 & 29.83 & 7.56 & $327.8 \pm 164.869$ & $496.2 \pm 220.3342$ & 0.66 & 0.231 \\
7111 & 30.48 & 7.65 & $268.3 \pm 134.2736$ & $373.6 \pm 185.0381$ & 0.72 & 0.393 \\
7210 & 33.02 & 7.80 & $297.8 \pm 158.0181$ & $429.0 \pm 178.9225$ & 0.69 & 0.176 \\
7307 & 38.60 & 7.91 & $2044.6 \pm 683.3091$ & $1568.3 \pm 293.77$ & 1.30 & 0.420 \\
\hline
\end{tabular}

SSP, standard spot protein; MW, molecular weight by kDa; PI, isoelectric point; GB, growing Berkshire; FB, finishing Berkshire. Spots of greater intensity in growing Berkshire are indicated by bold font.

shown). The results of SOM were similar to results of PDQuest analysis, and expression patterns of protein were divided into either Landrace and Berkshire or growing and finishing Berkshires. It suggests that the results of 2-DE were performed without error of experimental procedure and methods.

\section{Identification of proteins differentially expressed between breeds}

We then sought to identify the protein spots with differential expressions between pig breeds by PMF and CAF-MALDI sequencing (Tables 3 and 4). Among the 27 spots (except two spots expressed only in Landrace among 29 total, specifically 4002 and 4101) that were different between pig breeds, 24 spots were completely identified by PMF and CAF-MALDI sequencing. The other three proteins were identified by partial amino acid sequences and are unknown proteins.

Our analysis determined that the proteins specifically elevated in the Landrace muscle compared to the Berkshire muscle were: serum albumin precursor, sTnT (slow skeletal muscle troponin T), and myoglobin. Serum albumin, which is generated by the removal of 18 amino acids from serum albumin precursor, plays an essential role in maintaining os- 
Table 3. Proteins identified by PMF

\begin{tabular}{|c|c|c|c|c|}
\hline SSP & Identified protein & $\begin{array}{l}\text { Accession No. } \\
\text { (source) }\end{array}$ & $\begin{array}{c}\text { Sequence } \\
\text { coverage (\%) }\end{array}$ & $\mathrm{pI} / \mathrm{kDa}^{1}$ \\
\hline 6103 & Muscle creatine kinase & $\begin{array}{l}\text { gi|54111517 } \\
\text { (Sus scrofa) }\end{array}$ & 25 & $6.6 / 43.27$ \\
\hline 6105 & Muscle creatine kinase & $\begin{array}{l}\text { gi| } 54111517 \\
\text { (Sus scrofa) }\end{array}$ & 25 & $6.6 / 43.27$ \\
\hline 6505 & Chain A, structure of phosphotransferase Phosphoglucomutase & $\begin{array}{c}\text { gi } \mid 1942289 \\
\text { (Rabbit) }\end{array}$ & 29 & 6.6 / 61.69 \\
\hline 7102 & Tpi1 protein & $\begin{array}{c}\text { gi } \mid 38512111 \\
\text { (Rattus norvegicus) }\end{array}$ & 44 & $7.1 / 27.21$ \\
\hline 7107 & $\begin{array}{l}\text { Chain A, crystal structure of recombinant human triosephosphate } \\
\text { isomerase at } 2.8 \text { angstroms resolution. Triosephosphate isomerase } \\
\text { related human genetic disorders and comparison with the } \\
\text { trypanosomal enzyme }\end{array}$ & $\begin{array}{c}\text { gi|999892 } \\
\text { (Homo sapiens) }\end{array}$ & 32 & $6.5 / 26.81$ \\
\hline 7109 & Adenylate kinase isoenzyme 1 & $\begin{array}{c}\text { gi|125151 } \\
\text { (KAD1_PIG) }\end{array}$ & 56 & $8.6 / 21.74$ \\
\hline 7110 & Aldehyde dehydrogenase 1 family, member L1 & $\begin{array}{c}\text { gi| } 27532959 \\
\text { (Mus musculus) }\end{array}$ & 29 & $5.6 / 99.55$ \\
\hline
\end{tabular}

${ }^{1} \mathrm{pI} / \mathrm{kDa}$ : values registered in Genebank.

motic pressure by distributing fluids between the intravascular compartments and body tissues [7]. Serum albumin is also a serum carrier via nonspecific interactions with hydrophobic steroid hormones, as well as being a transport protein for hemin and fatty acids [20]. Although the specific function of TnT has not yet been identified, it is known that it is a component of the troponin complex, which blocks muscle contraction by forming a troponin-tropomyosin complex. Among the ten TnT isoforms in pigs, eight isoforms are fast-type isoforms and the other two are slow-type isoforms [16]. Fast-type TnT isoforms (fTnT) are highly expressed in fast skeletal muscle, whereas slow-type isoforms (sTnT) are expressed at low levels in the fast skeletal muscle [26]. In bovine muscle, a large number of slow fibers in the muscle indicate elevated expression of sTnT, whereas a large number of fast fibers indicate elevated expression of fTnT [3]. Based on the data described above, the increased level of sTnT in Landrace pigs versus Berkshire pigs may indicate that Landrace pigs have larger quantities of slow skeletal muscle. Myoglobin satisfies the oxygen requirement of muscle tissue by mediating oxygen transfer. We identified the partial amino acid sequences of spots 4002, 4101, and 5102, but these sequences had no homology with known proteins. Among them, spots 4002 and 4101 were proteins specifically expressed in Landrace pigs. Taken together, these data indicate that the Landrace longissimus dorsi muscle promotes complete oxidation and increased oxygen transfer mediated by myoglobin, which occurs as a result of increased amounts of slow skeletal muscle.

Proteins that were expressed specifically in Berkshire pigs were HSP27-1, fTnT, muscle creatine kinase, phosphoglucomutase 1 (PGM1), triosephosphate isomerase (Tpi1) and adenylate kinase isoenzyme 1 (AK1). Small heat shock proteins (HSPs) are HSPs with molecular weights less than $30 \mathrm{kDa}$, and these HSPs are critical for the stress response and other physiological activations. HSP27 and aB-crystallin are components of small HSPs and act as regulators of cytoskeletal filaments such as microfilament and intermediate filament [12]. HSP27 is an inhibitor of actin polymerization, and this inhibitory activity is inhibited by phosporylation [2]. The fTnT protein is involved in contraction of skeletal muscle, as described above.

Although most of the energy in skeletal muscle is produced by mitochondrial ATPase activity, the consumed intermediates (ADP or AMP) do not reach the ATPase active site due to limited permeation of adenine nucleotide. If necessary, muscle creatine kinase can supply energy by inducing ATP production [24]. PGM1 is an enzyme that catalyzes the transformation of glucose-1-phosphate into glucose-6-phosphate or vice versa, and functions in the storage and degradation of glucose. Tpi1 is an enzyme that catalyzes the transformation of dihydroxyacetone phosphate (DHAP) into glycerolaldehyde-3-phosphate, and plays an essential role in the Embden-Meyerhof pathway (EMP). AK mediates 
Table 4. Proteins identified by CAF-MALDI sequencing

\begin{tabular}{|c|c|c|c|c|}
\hline SSP & Identified protein & $\begin{array}{l}\text { Accession No. } \\
\text { (source) }\end{array}$ & Identified sequence & $\mathrm{pI} / \mathrm{kDa}^{1}$ \\
\hline 3102 & $\begin{array}{l}\text { Heat shock } 27 \mathrm{kDa} \\
\text { protein } 1\end{array}$ & $\begin{array}{l}\text { gi } \mid 4504517 \\
\text { (Homo sapiens) }\end{array}$ & LFDQAFGLPR & $6.0 / 22.78$ \\
\hline 4002 & Unknown & - & AFGQMPVPVPVVI & - \\
\hline 4101 & Unknown & - & IQWGTYQDYNEGNR & - \\
\hline 4607 & $\begin{array}{l}\text { Serum albumin } \\
\text { Precursor }\end{array}$ & $\begin{array}{l}\text { gi |5915682 } \\
\text { (ALBU_MOUSE) }\end{array}$ & DVFLGTFLYEYSR & $5.8 / 68.69$ \\
\hline 4608 & $\begin{array}{l}\text { Serum albumin } \\
\text { Precursor }\end{array}$ & $\begin{array}{l}\text { gi } \mid 5915682 \\
\text { (ALBU_MOUSE) }\end{array}$ & DVFLGTFLYEYSR & $5.8 / 68.69$ \\
\hline 5102 & Unknown protein & & NEGQGTYQDYNEGNR & \\
\hline 5201 & $\begin{array}{l}\text { Troponin T, slow } \\
\text { skeletal muscle }\end{array}$ & $\begin{array}{l}\text { gi |1174800 } \\
\text { (Homo sapiens) }\end{array}$ & YEINVLYNR & $5.9 / 32.95$ \\
\hline 5207 & $\begin{array}{l}\text { Troponin } \mathrm{T} \text {, slow } \\
\text { skeletal muscle }\end{array}$ & $\begin{array}{l}\text { gi|} \mid 1174800 \\
\text { (Homo sapiens) }\end{array}$ & YEINVLYNR & $5.9 / 32.95$ \\
\hline 5208 & $\begin{array}{l}\text { Troponin } \mathrm{T} \text {, slow } \\
\text { skeletal muscle }\end{array}$ & $\begin{array}{l}\text { gi | } 1174800 \\
\text { (Homo sapiens) }\end{array}$ & YEINVLYNR & 5.9 / 32.95 \\
\hline 5601 & $\begin{array}{l}\text { Serum albumin } \\
\text { Precursor }\end{array}$ & $\begin{array}{l}\text { gi } \mid 5915682 \\
\text { (ALBU_MOUSE) }\end{array}$ & DVFLGTFLYEYSR & $5.8 / 68.69$ \\
\hline 6101 & Unknown protein & - & NSVPTEVVSGSPPTAYNNFAR & - \\
\hline 6104 & Unknown protein & - & NSVPTEVVSGSPPTAYNNFAR & - \\
\hline 6107 & Unknown protein & - & NSVPTEVVGCAPPTAYNNFAR & - \\
\hline 6312 & $\begin{array}{l}\text { Troponin T, fast } \\
\text { skeletal muscle }\end{array}$ & $\begin{array}{l}\text { gi |33518637 } \\
\text { (Homo sapiens) }\end{array}$ & DLMELQALIDSHFEAR & $5.7 / 31.82$ \\
\hline 7006 & Myoglobin & $\begin{array}{l}\text { gi } \mid 226793 \\
\text { (Ondatra zibethicus) }\end{array}$ & HGBTVLTALGGILK & $8.7 / 17.13$ \\
\hline 7111 & $\begin{array}{l}\text { Muscle creatine } \\
\text { Kinase }\end{array}$ & $\begin{array}{l}\text { gi } \mid 21536288 \\
\text { (Homo sapiens) }\end{array}$ & SFLVWVNEEDHLR & $6.8 / 43.10$ \\
\hline 7210 & $\begin{array}{l}\text { Muscle creatine } \\
\text { Kinase }\end{array}$ & $\begin{array}{l}\text { gi } \mid 21536288 \\
\text { (Homo sapiens) }\end{array}$ & SFLVWVNEEDHLR & $6.8 / 43.10$ \\
\hline 7304 & $\begin{array}{c}\text { Troponin } \mathrm{T} \text {, fast } \\
\text { skeletal muscle }\end{array}$ & $\begin{array}{l}\text { gi|33518637 } \\
\text { (Homo sapiens) }\end{array}$ & DLMELQALIDSHFEAR & $5.7 / 31.82$ \\
\hline 7305 & $\begin{array}{c}\text { Troponin } \mathrm{T} \text {, fast } \\
\text { skeletal muscle }\end{array}$ & $\begin{array}{l}\text { gi } \mid 33518637 \\
\text { (Homo sapiens) }\end{array}$ & DLMELQALIDSHFEAR & $5.7 / 31.82$ \\
\hline 7307 & $\begin{array}{c}\text { Troponin } \mathrm{T} \text {, fast } \\
\text { skeletal muscle }\end{array}$ & $\begin{array}{l}\text { gi |33518637 } \\
\text { (Homo sapiens) }\end{array}$ & DLMELQALIDSHFEAR & $5.7 / 31.82$ \\
\hline 7502 & $\begin{array}{l}\text { Phosphogluco- } \\
\text { mutase } 1\end{array}$ & $\begin{array}{l}\text { gi } \mid 21361621 \\
\text { (Homo sapiens) }\end{array}$ & IALYETPTGWK & $6.3 / 61.45$ \\
\hline 7505 & Phosphogluco-mutase 1 & $\begin{array}{l}\text { gi } \mid 21361621 \\
\text { (Homo sapiens) }\end{array}$ & IALYETPTGWK & $6.3 / 61.45$ \\
\hline
\end{tabular}

${ }^{1} \mathrm{pI} / \mathrm{kDa}$ : values registered in Genebank.

the reaction $\mathrm{ATP}+\mathrm{AMP} \rightarrow 2 \mathrm{ADP}$, and this family is a strongly conserved enzyme. The AK reaction is critical for adenine nucleotide metabolism and the phosphate-mediated transfer of chemical energy into bioenergy. AK1 is among the AK isoenzyemes discovered in mammals and is specifically expressed in skeletal muscle [23]. Lastly, spots 6101, 6104 and 6107 could not be identified.

These data indicate that the longissimus dorsi muscle of
Berkshire pigs promotes fast energy production due to the elevated amount of fast energy-producing tissue predicted by fTnT. Additionally, the expression of muscle creatine kinase, PGM1, Tpi1 and AK1, also suggests that reduced oxidation occurs in the Berkshire muscle. The protein expression patterns in these two breeds indicate that the Berkshire longissimus dorsi muscle is comprised of more white fiber/fast twitch muscles and this muscle from 
Landrace pigs is comprised of red fiber/slow twitch muscles of Landrace pigs.

Identification of proteins differentially expressed according to growth stage

Proteins that were elevated in finishing Berkshire pigs $(110 \mathrm{~kg})$ were aldehyde dehydrogenase 1 family, member L1 (ALDHL1) and muscle creatine kinase. The ALDH1L1 gene in humans encodes 10-formyltetrahydrofolate dehydrogenase and catalyzes the reaction between 10-formyltetrahydrofolate, NADP, and water to form tetrahydrofolate, NADPH, and carbon dioxide. Tetrahydrofolate is a coenzyme for the metabolism of amino acids and nucleic acids, and NADPH serves as the reducing power for the biosynthetic reaction. Muscle creatine kinase produces energy in a manner different from ATPase, as described above.

Protein expression elevated in the growing Berkshire pigs (60-70 kg) were heat shock $27 \mathrm{kDa}$ protein (HSP27)-1, sTnT, fTnT, serum albumin precursor, PGM1, AK1 and Tpi1. These proteins aid in muscle function, as described above. In summary, the results from these studies suggest that the proteins elevated exclusively in the growing Berkshire pig promote functions related to growth and maintenance, such as fTnT and sTNT, as well as increased energy consumption and cytoskeleton maintenance. Additionally, the proteins expressed specifically in the finishing pig suggest that those muscles are specialized to support energy and reducing power.

\section{Functional analysis of identified proteins}

A total of 29 proteins differentially expressed between finishing Landrace and Berkshire pigs were identified. Among them, 11 proteins are known to have roles in metabolism and had the largest expression changes between two breeds (Fig. 3A). We identified changes in expression of four isoforms of muscle creatine kinase and two isoforms of PGM1. Contractile apparatus was discovered by all TnT isoforms. Three serum albumin precursor proteins located in different positions were identified that have structural functions. Additionally, one oxygen transporter and one defense protein were identified. In a previous study, [13] compared muscle tissue proteomes between Norwegian Landrace and Duroc pigs. They identified a change in expression of 50 proteins between Norwegian Landrace and Duroc. Among the 50 proteins, 13 were structural, 16 were metabolic enzyme, 15 were cellular defense/stress proteins and 6 were
(A)

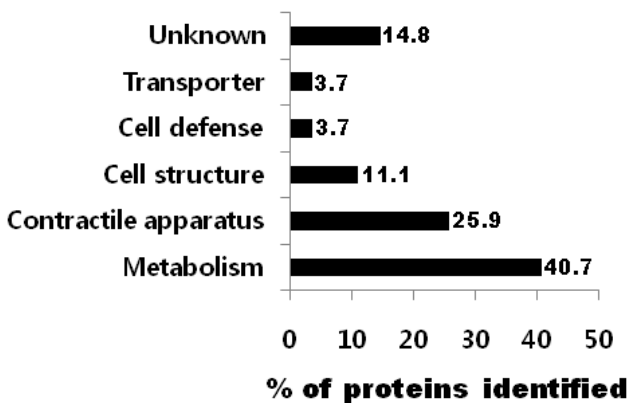

(B)

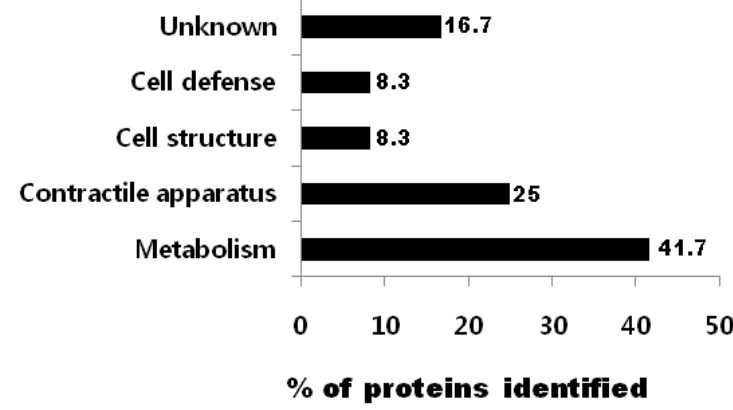

Fig. 3. Functional analysis of identified proteins. (A) Proteins expressed in a differential pattern between Landrace and Berkshire longissimus dorsi muscles. (B) Proteins expressed in a differential pattern between growing and finishing Berkshire longissimus dorsi muscles.

miscellaneous proteins. Protein expression changes, which were identical in both this and Hollungs' studies, were creatine kinase and Hsp27. Significantly, creatine kinase was detected in both studies in various isoforms.

A total of 12 proteins in this study were identified that are differentially expressed between growing and finishing Berkshire pigs. Among them, five proteins were related to metabolism and exhibited the largest changes in expression between the two age groups (Fig. 3B). Contractile apparatus was discovered by all troponin $\mathrm{T}$ isoforms. One protein each had functions related to structure and defense. These results were entirely different from those of [13].

\section{Acknowledgements}

This work was supported by "Cooperative Research Program for Agriculture Science and Technology Development (Project No. PJ004186)," Rural Development Administration, Republic of Korea, and Priority Research Centers Program through the National Research Foundation of Korea (NRF) funded by the Ministry of Education, Science and Technology (2009-0093813). 


\section{References}

1. Anderson, N. L., Esquer-Blasco, R., Hofmann, J. P. and Anderson, N. G. 1991. A two-dimensional gel database of rat liver proteins useful in gene regulation and drug effects studies. Electrophoresis 12, 907-930.

2. Benndorf, R., Hayeb, K., Ryazantsev, S., Wieske, M., Behlke, J. and Lutsch, G. 1994. Phosphorylation and supramolecular organization of murine small heat shock protein HSP25 abolish its acting polymerization-inhibiting activity. J. Biol. Chem 269, 20780-20784.

3. Bouley, J., Chambon, C. and Picard, B. 2004. Mapping of bovine skeletal muscle proteins using two-dimensional gel electrophoresis and mass spectrometry. Proteomics 4, 1811-1824

4. Bradford, M. M. 1976. A rapid and sensitive method for the quantitation of microgram quantities of protein utilizing the principle of protein-dye binding. Anal. Biochem 72, 248-254.

5. Candek-Potokar, M., Zlender, B., Lefaucheur, L. and Bonneau, M. 1998. Effects of age and/or at slaughter on longissimusdorsimuscle: Biochemical traits and sensory quality in pigs. Meat Science 48, 287-300.

6. Cieslak, D., Kapelanski, W., Blicharski, T. and Pierzchala, M. 2000. Restriction fragment length polymorphisms in $m y-$ ogenin and myf3 genes and their influence on lean meat content in pigs. J. Anim Breed Genet. 117, 43-55.

7. Correa-Pérez, J. R., Fernández-Pelegrina, R., ZarmakoupisZavos, P. N. and Zavos, P. M. 2003. The effect of colloid osmotic pressure in human spermatozoa exposed to hypoosmotic conditions. Andrologia 35, 117-120.

8. Degrelle, S. A., le Blomberg, A., Garrett, W. M., Li, R. W. and Talbot N. C. 2009. Comparative proteomic and regulatory network analyses of the elongating pig conceptus. Proteomics 9, 2678-2694.

9. Dongxia, W., Kalb, S. R. and Cotter, R. J. 2004. Improved procedures for $\mathrm{N}$-terminal sulfonation of peptides for matrix-assisted laser desorption/ionization post-source decay peptide sequencing. Rapid Commun. Mass Spectrom 18, 96-102.

10. Du, M., Shen, Q. W. and Zhu, M. J. 2005. Role of beta-adrenoreceptor signaling and AMP-activated protein kinase in glycolysis of postmortem skeletal muscle. J. Anim Breed Genet. 53, 3235-3239.

11. Gupta, M. K., Jang, J. M., Jung, J. W., Uhm, S. J., Kim, K. P. and Lee, H. T. 2009. Proteomic analysis of parthenogenetic and in vitro fertilized porcine embryos. Proteomics 9, 2846-2860.

12. Hino, M., Kurogi, K., Okubo, M. A., Murata-Hori, M. and Hosoya, H. 2000. Small heat shock protein 27 (HSP27) associates with tubulin/microtubules in HeLa cells. Biochem Biophys. Res. Commun. 271, 164-169.
13. Hollung, K., Grove, H., Faergestad, E. M., Sidhu, M. S. and Berg, P. 2009. Comparison of muscle proteome profiles in pure breeds of Norwegian Landrace and Duroc at three different ages. Meat Sci. 81, 487-492.

14. Kim, J. M., Choi, B. D., Kim, B. C., Park, S. S. and Hong, K. C. 2009. Associations of the variation in the porcine myogenin gene with muscle fibre characteristics, lean meat production and meat quality traits. J. Anim Breed. Genet. 126, 134-141.

15. Kim, N. K., Joh, J. H., Park, H. R., Kim, O. H., Park, B. Y. and Lee, C. S. 2004. Differential expression profiling of the proteomes and their mRNAs in porcine white and red skeletal muscles. Proteomics 4, 3422-3428.

16. Kitamura, S., Muroya, S., Nakajima, I., Chikuni, K. and Nishimura, T. 2006. Amino acid sequences of porcine fast and slow troponin T isoforms. Biosci. Biotechnol. Biochem 70, 726-728.

17. Miron, T., Vancompernolle, K., Vandekerckhove, J., Wilchek, M. and Geiger, B. 1991. A 25-kD inhibitor of acting polymerization is a low molecular mass heat shock protein. J. Cell Biol. 114, 255-261.

18. Muráni, E., Ponsuksili, S., Srikanchai, T., Maak, S and Wimmers, K. 2009. Expression of the porcine adrenergic receptor beta 2 gene in longissimus dorsi muscle is affected by cis-regulatory DNA variation. Anim Genet. 40, 80-89.

19. Nonogaki, K. 2000. New insights into sympathetic regulation of glucose and fat metabolism. Diabetologia 43, 533-549.

20. Peters, T. 1995. All about albumin: biochemistry, genetics and medical applications. San Diego, Academic Press.

21. Qvisth, V., Hagstrom-Toft, E., Enoksson, $\mathrm{S}$ and Bolinder, J. 2008. Catecholamine regulation of local lactate production in vivo in skeletal muscle and adipose tissue: role of adrenoreceptor subtypes. J. Clin. Endocrinol. Metab. 93, 240-246.

22. Shevchenko, A., Wilm, M., Vorm, O and Mann, M. 1996. Mass spectrometric sequencing of proteins from silver-stained polyacrylamide gels. Anal. Chem 68, 850-858.

23. Tanabe, T., Yamada, M., Noma, T., Kajii, T and Nakazawa, A. 1993. Tissue-specific and developmentally regulated expression of the genes encoding adenylate kinase isozymes. J. Biochem 113, 200-207.

24. Ventura-Clapier, R., Kaasik, A and Veksler, V. 2004. Structural and functional adaptations of striated muscles to CK deficiency. Mol. Cell Biochem 256, 29-41.

25. Warriss, P. D and Lister, D. 1982. Improvement of meat quality in pigs by beta-adrenergic blockade. Meat SCi. 7, 183-187.

26. Yu, Z. B, Gao, F., Feng, H. Z. and Jin, J. P. 2007. Differential regulation of myofilament protein isoforms underlying the contractility changes in skeletal muscle unloading. Am J. Physiol. Cell Physiol. 292, 1192-1203.

27. Zhang, Y., Proenca, R., Maffei, M., Barone, M, Leopold, L. and Friedman, J. M. 1994. Positional cloning of the mouse obese gene and its human homologue. Nature 372, 425-431. 


\section{초록 : 돼지의 품종 및 성장 단계에 따른 등심조직의 단백질 발현 양상 비교, 분석}

김병욱 $^{\dagger} \cdot$ 김삼웅 $^{2^{\dagger}} \cdot$ 홍연희 $^{1} \cdot$ 정미애 ${ }^{1} \cdot$ 류연선 $^{3} \cdot$ 박화춘 $^{4} \cdot$ 정종현 $^{4} \cdot$ 권영민 $^{5} \cdot$ 최인순 $^{6} \cdot$ 이상석 $^{7} \cdot$ 김철욱 $^{1} \cdot$ 조광근 ${ }^{1}$ *

( ${ }^{1}$ 경남과학기술대학교 동물소재공학과, ${ }^{2}$ 경남과학기술대학교 양돈과학기술센터, ${ }^{3}$ 우석대학교 동물건강관리 학과, ${ }^{4}$ 남원 다산종돈, ${ }^{5}$ 알칸소 주립대학교, ${ }^{6}$ 신라대학교 생물과학과, ${ }^{7}$ 순천대학교 동물자원과학과)

Landrace와 Berkshire의 longissimus dorsi muscle으로부터 단백질 발현양상의 차이를 보기 위하여 2-DE실험을 통하여 분석한 결과 Landrace 에서 특이적으로 발현 양이 증가한 단백질들은 serum albumin precursor, tropo$\operatorname{nin} \mathrm{T}$ (TnT; slow skeletal muscle), myoglobin였다. Berkshire에서 특이적으로 발현 양이 증가한 단백질들은 heat shock $27 \mathrm{kDa}$ protein 1, troponin T (fast skeletal muscle), muscle creatine kinase, phosphoglucomutase 1, triosephosphate isomerase (Tpi 1), adenylate kinase isoenzyme 1 (AK1)였다. Landrace의 longissimus dorsi muscle 에서는 slow skeletal muscle과 연관된 단백질들이 발현된 반면에 Berkshire에서는 fast skeletal muscle, 물질대사 경로, 에너지 생산과 관련된 단백질들이 발현되었다. Berkshire를 이용하여 성장단계별로 단백질 발현을 분석해 본 결과 growing Berkshire에서 발현이 증가한 단백질은 aldehyde dehydrogenase 1 family, member L1 (ALDHL1)와 muscle creatine kinase이고 finishing Berkshire에서 발현이 증가한 단백질은 heat shock $27 \mathrm{kDa}$ protein 1, TnT (slow skeletal muscle), TnT (fast skeletal muscle), serum albumin precursor, PGM 1, AK 1, Tpi 1였다. 이 결과는 Finishing Berkshire의 등심에서는 growing Berkshire에 비교하여 골격근육, 에너지물질대사, 세포골격 등이 보다 활성화된 것으로 사료된다. 